\title{
The Principales of Philip II: Vassalage, Justice, and the Making of Indigenous Jurisdiction in the Early Colonial Philippines
}

\author{
Abisai Perez Zamarripa
}

In early May, 1590, native chief Don Felipe Tuliao of Guagua (Pampanga, the Philippines) testified, at the request of Spanish Governor Gómez Pérez Dasmariñas, about the current state of local justice. A year before, Dasmariñas had mandated to summarily conduct, i.e. resolve orally without keeping written records, all the local lawsuits, and he requested that the Crown make his order irrevocable. To achieve his goal, the governor resorted to the testimonies of principales, as the Spaniards called the indigenous rulers of the Philippines. According to principal Tuliao, since "the lawsuits are determined verbally without writing", natives no longer filed "unjust lawsuits proven with false witnesses" or spent their goods on "the many fees that the judges and their officials" required. In Tuliao's opinion, a royal confirmation of summary justice "would be a particular merced (favor) to these islands" because it dealt with two obstacles in the dispensing of justice explored in this paper: the shortage of colonial magistrates and the abuses that they performed against the natives. ${ }^{1}$ Tuliao's testimony provides insight into the dispensing of justice by the Spanish Crown to its Philippine subjects - a key strategy for keeping the newly conquered islands under its control. Thus, the question arises, which principles governed the administration of justice in the early colonial Philippines and how did the Crown manage this?

1 "este testigo ha conocido ha visto oír de todos los pleitos así civiles como criminales [...] con que los indios unos a otros se ponían demandas injustas probando con testigos falsos [...] gastando en ello sus haciendas por los muchos derechos que los jueces y sus oficiales pedían [...] y ha visto que los demás pleitos se determinan verbalmente sin escribir y lo que se escribe es con mucha brevedad que todo le ha parecido a este testigo muy bien [...] sería particular merced para todas estas islas que su majestad confirmase la dicha orden". AGI, Filipinas, 34, n. 91, fols. 1014r-1028v. The translation of all quotations used in this chapter are mine. 
As legal historians, such as António Manuel Hespanha, Carlos Garriga, Tamar Herzog, Víctor Tau Anzoátegui, and Lara Semboloni, have extensively demonstrated, the early modern Iberian empires rested upon a judicial model of government. ${ }^{2}$ In the Spanish Monarchy, to govern essentially meant to mete out justice, being that the king's main function was to sustain and reestablish an original normative order provided by God. ${ }^{3}$ Similarly, in Iberian political culture, government involved judgment following the principle of justice: God endowed the world with a perfect order that guaranteed each person what he or she was entitled to. ${ }^{4}$ Humanity had organized itself into communities receiving from God's iurisdictio (jurisdiction), operating under the mandate of exercising justice over community members in order to preserve the harmony dictated by divine will. ${ }^{5}$ Drawing from this idea of justice, Spanish political culture acknowledged the monarch as the sovereign and supreme guarantor of justice of his realm because the communities handed him their jurisdiction. ${ }^{6}$ Since the king stood out as the highest judge in the kingdom, his main duty was to dispense justice by reestablishing equity among all his subjects.

This paper traces the role of these political principles in the development and management of justice in the early colonial Philippines, by tracking how the Spanish Crown incorporated Philippine natives as vassals, administered justice over them, and acknowledged the jurisdiction of the indigenous nobility. The first section introduces the origins of the contractual relationship between the Spanish king and Philippine natives. In explaining the legal grounds that guided the conquest of the archipelago, this section shows that the Spanish Crown branded Philippine natives as vassals, drawing from the theological and juridical concept of friendship. The second section analyzes how the colonial authorities organized the jurisdictions in the Philippines in line with the governor's authority and Spanish settlement patterns. It also explains the problems in the administration of justice because colonial magistrates owned encomiendas - indigenous labor drafts granted by the Crown to Spanish conquistadors. The third section explores the recognition of the jurisdiction of native elites resulting from the lobbying for and formation of local customs by ecclesiastical actors. It also suggests that, although indigenous magistrates were the cornerstones of daily local justice, substantial records do

\footnotetext{
2 Hespanha, As vésperas; Garriga, "Sobre El Gobierno"; Herzog, Los ministros; Tau Anzoátegui, ElJurista; Semboloni, La construcción.

3 Vallejo, "El Cáliz de Plata"; Bastias Saavedra, "Jurisdictional Autonomy".

4 Agüero, "Las Categorías Básicas"; Garriga, "Sobre el Gobierno".

5 Agüero, "Las Categorías Básicas".

6 Fioravanti, “Estado y Constitución”.
} 
not exist due to the preeminence of the oral culture among Philippine peoples and the historical contingency that precipitated the absence of archival evidence.

Since there is a lack of testimonies by indigenous actors from the early colonial period, this research adopts two strategies. First, it draws upon imperial legislation and official correspondence between Spanish agents and the Crown to read between the lines following the indigenous experience in the face of Spanish colonization. The decrees issued to protect indigenous vassals and the reports on their mistreatment by the colonizers reveal the recurrent concerns and challenges that shaped the administration of justice during the early colonial Philippines. Second, this paper juxtaposes the developments in the archipelago with the Spanish American experience. Since the beginning of the conquest and colonization, the Spanish Crown attempted to reproduce in the Philippines the legal structure that it previously implemented in its American dominions. Accordingly, this paper attempts to understand and reconstruct the elusive role of Philippine native elites in the colonial justice system through the analysis of the strategies and reactions that unfolded in Spanish America.

So far, research on the role of Philippine natives under Spanish rule mainly focuses on social and economic issues. John L. Phelan, Patricio Hidalgo, and Luis Alonso Álvarez argue that the Crown decided to preserve the nobility status of the datus (native chiefs, also called principales in Spanish) and to maintain the barangay institution - a kinship-oriented community formed by 40-50 households and led by a datu —-merely for economic reasons. ${ }^{7}$ Indeed, both the barangay and the datus became key instruments not only in the organization and collection of indigenous tribute payments, but also in the formation of the colonial militias that sustained Spanish rule. ${ }^{8}$ Consequently, scholarship has overlooked the indigeneity of the process: native elites and native customs were critical components in the administration of justice. They permitted the management of daily justice at a local level without the presence of Spanish agents. This paper proposes that, in line with the ideological background of Spanish legal culture, the Philippine principales wielded indigenous jurisdiction, which involved the ability to mete out justice among native subjects concerning minor crimes within their barangays. ${ }^{9}$ Despite the lack of

7 Phelan, The Hispanization of the Philippines; Hidalgo Nuchera, Encomienda, tributo y trabajo; Hidalgo Nuchera, La recta administración; Alonso Álvarez, El costo del imperio, 93-142.

8 See the recent works of Borao Mateo, "Contextualizing the Pampangos"; Mawson, "Philippine Indios"; Crossley, "Dionisio Capulong”.

9 Another definition of indigenous jurisdiction that dovetails with the specific features of colonial Mexico is offered in Premo and Yannakakis, "A Court of Sticks". 
Spanish agents throughout the colonial period, the Crown was able to govern an archipelago of 7,00o culturally and geographically diverse islands thanks to the indigenous jurisdiction hidden beneath Spanish rule. ${ }^{10}$

Conquest through Pacificación: Friendship, Vassalage, and Conversion

Spanish imperial ambitions in Asia prompted the colonization of the Philippines; when Hernán Cortés defeated the Mexica in 1521, the Crown supported his explorations toward the Pacific Ocean aimed at establishing contact with the mythical Catay and Cipango (China and Japan). ${ }^{11}$ The Portuguese conquests of Malacca (1511) and Ternate (1512) drove the Spaniards to redouble their efforts in establishing a secure trade route with Asia. The first Spanish endeavors to connect Asia and America unfolded with the circumnavigation voyage of Fernando Magallanes and Sebastián Elcano (1519-1522) and two failed campaigns (in 1527 and 1542) in the Maluku Islands (eastern Indonesia). ${ }^{12}$ Since these journeys paved the way for the conquest of the Philippines, scholarly literature tends to overemphasize the objective of establishing a commercial route between the two continents. It therefore overlooks the Crown's key concern regarding how to integrate the indigenous peoples into its realm..$^{13} \mathrm{~A}$ careful analysis of the instructions that Captain Miguel López de Legazpi followed when conducting the colonial enterprise reveals the Spanish Crown's early strategy to bestow upon Philippine natives the status of vassals.

By the time of Legazpi's journey (1564), the Crown's approach to securing new domains differed from the one proclaimed during the early 16 th century. Initially, Spanish monarchs justified the possession of their overseas domains by considering them donations from the Pope since he commended to them the religious conversion of indigenous peoples who were regarded as heathens. Complying with this papal mandate, since 1514 Spanish conquistadors had to perform the Crown's protocol of requerimiento, which justified the conquest

10 Ethnohistorical research has demonstrated the prevalence of customs in local daily life as well as how natives partially adopted the culture of the colonizers. See Scott, Barangay; Concepcion, "Negotiating Land".

11 León-Portilla, "Lo que supo y no supo Hernán Cortés”; Gruzinski, El águila y el dragón, $52-59$.

12 Bernabeú, "Magallanes: retrato de un hombre"; Knauth, "Los dos Fernandos"; Andaya, "Los primeros contactos de los españoles".

13 Cervera, “'Las Molucas o China?”; Ollé, “A inserção das Filipinas”; Gruzinski, El águila y el dragón, 94-139. 
of natives by just war. It demanded that indigenous peoples provide unconditional and immediate recognition of the Spanish kings as their "superior lords [...] by virtue of the said donation". If they refused to comply, the conquistadors became authorized to wage war against them and take them as slaves without any moral constraint reasoning that all "the deaths and damage that occurred" were the natives' fault. ${ }^{14}$

In the mid-16th century, pro-Indianist theologians Francisco de Vitoria and Bartolomé de Las Casas contested the requerimiento's principles. Both Dominican thinkers argued that natives were conscious human beings who possessed the right to self-determination; regardless of their ignorance of Christian religion, indigenous peoples were the rightful owners of the land they inhabited and could thus neither be enslaved nor stripped of their properties by force. ${ }^{15}$ Such arguments undermined the legitimacy of the papal donation and the requerimiento and urged the Crown to halt the violent conquests unfolding in the New World. Las Casas questioned whether God would approve of the reading of requerimientos to "the peaceful and quiet indios" and the destruction that Spaniards carried out when natives refused to obey a "king who they never heard or saw", particularly when royal envoys were "so cruel, so ruthless, and horrible tyrants". 16

In response to pro-Indianist criticism, in 1556 the Crown decreed a new approach to colonial expansion. In that year, Emperor Charles $\mathrm{v}$ forwarded the Viceroy of Perú, Marqués de Cañete, the Instrucciones para las nuevas poblaciones y descubrimiento to conduct new colonial enterprises following the strategy of pacificación (pacification), i.e., conquest through pacts of friendship. The orders established that Spaniards should found new settlements "close to the lands of the natives who until now are not subjugated", without "taking anything from the indios without their consent". Once the Spaniards settled, they must seek "peace and friendship with the indios who dwell on that land" by treating them well, protecting them, "reducing them to buena policía (order)", and converting them to Catholicism. While the requerimiento demanded that the natives surrender, the pacificación sought to persuade them through good actions. If, after three attempts of inducement, the indigenous peoples still refused to welcome the Spaniards, the invaders could then wage war against them, "defending themselves from the said naturales (natives) without doing any more harm than was necessary. ${ }^{17}$ Supposedly, Spaniards would no longer

\footnotetext{
14 Encinas, Cedulario Indiano, vol. IV, 226-227.

15 Phelan, "Some Ideological Aspects"; de la Hera, "El dominio español”; Wagner, "Francisco de Vitoria".

16 Las Casas, Tratados, vol. I, 51.

17 AGI, Lima, 567 , L.8, fols. $148 \mathrm{r}-151 \mathrm{v}$.
} 
pursue aggressive conquests, but defensive wars instead. Yet, the same goal prevailed: the religious conversion of indigenous peoples.

The shift from conquest to pacification could therefore appear inconsequential, since ultimately the new approach similarly legitimized Spanish subjugation over the natives in God's name, either by persuasion or force. But contrary to the requerimiento, the pacificación introduced a legal-theological concept that changed how Spaniards now perceived and should treat indigenous peoples: friendship. As historiography widely explains, pro-Indianist thought of the 16th-century Iberian world was inspired by Thomas Aquinas' idea of natural law. ${ }^{18}$ Aquinas considered that the human being, as a rational and free being by God's design, must follow his own natural inclinations dictated by reason.

Sociability and friendship were seen as rational inclinations since people attain the common good-the improvement of the spirit and the salvation of the soul-only by living in community and establishing relationships of respect and mutual help. ${ }^{19}$ By stating that the Spanish king's main purpose was to "form friendships with them [the natives] and teach them to live politically and know God",20 the pacificación recognized that indigenous peoples were able to act as rational human beings. If they accepted Spanish friendship, natives would demonstrate their rational capacity to live within the king's realm, the community that guaranteed them protection, and, more importantly, Christian salvation. If natives refused such a friendly invitation, then they showed a lack of rationality. It was inconceivable to reject Christ's religion of love, which Aquinas regarded as a feeling that all rational beings pursue. Thus, while the requerimiento regarded natives as barbarians who should be subjugated by force, the pacificación considered them free and rational peoples able to embrace Spanish friendship, but only if they accepted Christianity.

The instructions that Legazpi received from the Real Audiencia (royal court) of Mexico to conduct the Philippine expedition reveal that the Crown planned to integrate Philippine natives following the pacification strategy. Drafted by Viceroy Luis de Velasco, and later approved by the Spanish king, Legazpi's instructions stated that his main objective was to "bring the natives of those parts to the knowledge of our holy Catholic faith and to discover the return route to this New Spain". Like the Instrucciones forwarded to the Viceroy of Perú in 1556, Legazpi's instructions emphasized the mission of establishing "with the natives all good friendship and peace". ${ }^{21}$ As Pedro Cardim explains,

\footnotetext{
18 Duve, "La Escuela de Salamanca".

19 Cortés Pacheco, "La amistad política".

20 AGI, Lima, 567, L.8, fol. 148v.

21 AGI, Patronato, 23, r. 12, fol. 34r-34v.
} 
friendship, as a legal and theological category, dictated guidelines of behavior whereby the monarch must express his love and respect to his subjects and other rulers. ${ }^{22}$ Since Legazpi's instructions reflected this Thomistic notion of friendship, they also set rules of behavior for the Spaniards when encountering the indigenous peoples of the archipelago.

Generosity and respect were two key elements that set the grounds for friendship. According to the instructions, during the first encounter, Legazpi must give "to the señores principales (native chiefs) [...] the gifts you think convenient and give them all good treatment" to demonstrate the king's generosity. In doing so, Spaniards were showing that their monarch regarded the indigenous chiefs as señores principales (sovereign lords), emphasizing the expedition's purpose to establish peaceful relationships between equal sovereigns. The instructions specified that "the natives of those lands [...] are gente politica y rica (rich and organized people) where there are great princes" with whom the "powerful King of Castile" desired to "have all good friendship and brotherhood so that among the subjects and vassals there could exist communication and trade". ${ }^{23}$ Yet, a commercial agreement was not the main purpose of the expedition but was in fact the first step toward the Spaniards befriending the natives and gaining their confidence. Thus, Legazpi and his crew had to primarily act as royal envoys, not as conquistadors.

Once captain Legazpi had befriended the natives, then he could proceed to settle there. If the expedition found "such rich and high quality [land] that you must populate it", Legazpi must do it "in the part and place that best suits and where best friendship" has been established with the indigenous peoples. If, for some reason, Legazpi was unable to remain in the new settlement, "some religious people and some Spaniards" must stay in order to secure "the conversion of the natives as to preserve the friendship and peace that you will leave settled with them." ${ }^{24}$ Occupying the land not only strengthened the friendship between the Spanish king and the natives, but it also guaranteed the possession of the land through the subjugation of its inhabitants. Accepting Spanish friendship implicitly conveyed Christian conversion, obedience to a new sovereign, and, consequently, incorporation into a new polity: the Spanish Monarchy.

The instructions of pacification projected that the conquest of the Philippines required the acquiescence of local populations and Legazpi fitted the profile of leader for such an enterprise. Unlike the Spanish conquistadors who fought in the New World, Legazpi was not a soldier; however, he was well-versed

\footnotetext{
22 Cardim, "Amor e amizade".

23 AGI, Patronato, 23, r. 12, fol. 13v.

24 AGI, Patronato, 23, r. 12, fol. 33r.
} 
in Spanish legal culture and had served as the main notary of the cabildo and Casa de Moneda (mint) of Mexico City. ${ }^{25}$ Despite his lack of maritime experience, Legazpi became the leader of the expedition because his private wealth greatly contributed to the journey. In addition, he was a close friend of Friar Andrés de Urdaneta, the veteran campaigner of the Spanish expansion toward Southeast Asia. ${ }^{26}$ Legazpi had also worked as one of the personal notaries of New Spain's Archbishop and Inquisitor Juan de Zumárraga, who had carried out an aggressive persecution against the indigenous nobility to erase their ancient beliefs. ${ }^{27}$ Before he turned into the leader of the Philippine expedition, Legazpi had therefore been a close eyewitness of the religious persecution against natives and the gradual enforcement of laws to protect them. Given his experience, the Crown expected that he would treat indigenous peoples with "a lot of respect as if they were people of our policía (order)" because they are "men of good reason [...] and white like us". ${ }^{28}$ As a skilled notary, Legazpi would be expected to comply with the royal instructions.

The expedition reached the Philippines in early April, 1565 and by the end of that month it arrived at the city-port of Cebu, whose subjugation Legazpi depicted as a sublime act of friendship. Initially, Tupas, lord of Cebu, fiercely repelled the invaders, but he and his people had to flee to the mountains. After a skirmish, the Spaniards captured "two women and two girls of the nobility [that were] kept with great care". The women were relatives of chief Simaquio, Tupas' close ally. Simaquio tried to free his wife and daughters, offering in exchange his life and that of his followers so the Spanish captain could "do his will and hold them as slaves or sell them or send them to Castile". Legazpi responded that the only thing he wanted was "peace, friendship, and favor, and help and protection which he had offered to them in the name of His Majesty", stressing his selfless intention of serving only the Spanish king. Since friendship conveyed protection and mutual respect, Legazpi highlighted that the captive women's honor had been defended and that he had lodged them "as if he had them in his own house". Such good treatment only revealed, according to Legazpi, all the "good deeds and favors in His Majesty's name" that Philippine natives could receive once they accepted becoming "vassals of the King of Castile". ${ }^{29}$

\footnotetext{
25 Sanz y Díaz, Legazpi; Muro, La expedición Legazpi-Urdaneta, "Título escribano público de México: Miguel López de Legazpi”, AGI, Patronato, 18o, r. 56.

26 Barandica, "Andrés de Urdaneta".

27 Greenleaf, Zumárraga; AGNM, Inquisición, vol. 72, exp. 32.

28 AGI, Patronato, 23, r. 12.

29 AGI, Patronato, 23, r. 22.
} 
In order to persuade chief Simaquio, Legazpi allowed him to see and speak with his captive family. After his wife told him about "the good actions and merced (courtesy) she had received from the governor", Simaquio then accepted "to be friend and vassal of the King of Castile and to settle peace and friendship perpetually" ${ }^{30}$ Furthermore, he promised to convince Tupas and the other principales of Cebu to do the same, which was eventually achieved.

Ultimately, to become the friend of the Spanish king meant becoming his vassal. Vassalage was a contractual relationship that stemmed from a pact between a lord and a free man, who voluntarily accepted to obey and serve the lord in exchange for protection. Spanish friendship, as stated in the pacificación instructions, set the grounds for a relationship of vassalage based on obedience and a promise of safeguard. First, since friendship was a rational inclination of free peoples, when natives accepted to befriend the king, it was assumed that they were acting voluntarily and freely. Thus, the first condition of a contract of vassalage was that the person becoming a vassal was free to enter into it. In addition, the pacificación instructions stated that the friendship offered by the king also involved his protection, meaning that the free man's consent was the second condition for vassalage, i.e., a free man requested and accepted protection from a lord. ${ }^{31}$

The contractual nature of indigenous vassalage involved mutual responsibilities. The king must guarantee the wellbeing of his indigenous vassals by protecting them, hearing their petitions through his representatives-i.e. the Viceroy, the Real Audiencia, the protector de indios - forbidding their enslavement, and recognizing some of their prehispanic practices as legitimate sources of law. ${ }^{32}$ Thus, royal tutelage was meant to be under the king's jurisdiction: the king, and not a private person, was the supreme judge who could decide what was in the best interest of his native vassals. In exchange for the king's protection, the natives had to render him obedience, allegiance, and loyalty. All these obligations were comprised in the payment of tributes which sustained the king's realm. ${ }^{33}$ While the king provided protection, native vassals primarily helped him with their labor: either producing for the king's treasury or working in his estates or public works.

Spanish legal culture acknowledged the reciprocal relationship between the king and his vassals, highlighting the royal authority and the virtue of loyalty. The Siete Partidas stated that the lord "has commandment and power over

30 AGI, Patronato, 23, r. 22.

31 Ganshof, El feudalismo, 111-16o; Reynolds, Fiefs and Vassals, 17-19.

32 Ruiz Medrano, Mexico's Indigenous Communities, 11-68.

33 Menegus, "Alcabala o Tributo". 
all those who live in his land", while vassals "receive honor and benefit from [their] lords" as long as they fulfill their duty "to love and honor and keep" their lord. ${ }^{34}$ Sebastián de Covarrubias' dictionary states that a vassal "is the one who lives in the land of a lord whom he recognizes and respects as such [...] insofar as he promises to be faithful", while the lord wields authority "to honor and benefit who is virtuous and to punish and reduce the one who is cruel." ${ }^{35}$ As Xavier Gil notes, Spanish political culture stressed the value of loyalty because it guaranteed the keeping and safeguarding of the polity. ${ }^{36}$ As vassals, natives also became members of a community that they had to keep and safeguard, particularly because the Spanish Monarchy carried out the providential mission to expand and defend the true faith.

Because religion justified the subjugation of indigenous peoples and conditioned their membership to the polity, the religious identity of Philippine natives was an essential issue within the pacification strategy. After the conquest of Cebu, Legazpi informed King Philip II that numerous moros-as the Spaniards called the Muslims-inhabited the archipelago. Still, he considered that most of them had "little knowledge of the law which they profess, beyond practicing circumcision and refraining from pork". For this reason, he claimed, natives could be "easily converted to our holy Catholic faith". ${ }^{37}$ Such observations were relevant at a time when the Crown had enforced harsh policies against Muslims and Jews in its dominions while it struggled in the Mediterranean against the Ottoman Empire. ${ }^{38}$ Aspiring to become the defender of Christianity, the Spanish Monarchy endorsed the slavery and dispossession of Muslims. ${ }^{39}$ Therefore, downplaying the Muslim faith of Philippine natives was instrumental in achieving their peaceful integration into the Spanish Crown.

The Spanish king insisted on the pacificación as a way to subjugate Philippine natives, whom he regarded as heathens waiting for evangelization. Soon after receiving the first news from the archipelago, King Philip II reminded Legazpi of his "sensible policy in not waging war [...] unless you should be provoked and in your own defense". He ordered that the expedition should attempt "by all good means to attract the natives to the service of God our Lord and mine". If the moros "come for the purpose of spreading their cursed Mahometan worship" then Legazpi should proceed with a defensive war,

\footnotetext{
$34 \quad$ Siete Partidas, title 25, laws 1 and 6.

35 Covarrubias, Tesoro de la lengua, "vasallo".

36 Gil Pujol, "The Good Law".

37 López de Legazpi, "Relation of the Filipinas Islands and of the Character and Conditions of their Inhabitants", vol. 34, 54-61.

38 Hess, "The Moriscos"; Constable, To Live like a Moor, 1-14.

39 González Arévalo, "Cautiverio y esclavitud".
} 
which gave him the right to seize their property and enslave the captives. But the king strictly forbade the slavery of "those who were indios who may have adopted the worship of Mahomet" through a reminder that the main objective was "to persuade them to accept our holy Catholic faith". ${ }^{40}$

King Philip II's resolve in favor of the pacificación strategy derived from his idea that among Philippine natives there existed moros "by birth and nation" and "indios" who had converted to Islam. ${ }^{41}$ While the first were enemies of the empire and responsible for Muslim proselytism, Philippine natives-labeled as indios -were acknowledged as heathens; Muslims had known and rejected the true faith, whereas natives were considered to have overlooked the Christian faith and were therefore waiting for redemption through evangelization. Thus, for King Philip II, although some Philippine indios had been corrupted by Islam, they were mostly considered pagans who he could bring "to a civilized life and [...] separate them from their vices, sins, and evil customs". ${ }^{42}$

King Philip II's stance made the pacification of Manila possible, even though its rulers professed Islam. As some scholars have suggested, Manila's rulers not only professed Islam, but they were also relatives of Brunei's royal family. ${ }^{43}$ Foreseeing the strategic position of Manila, which connected the archipelago with South China, the Indian Ocean, and the Maluku islands, Legazpi sent a small expedition under the command of Martín de Goiti to "pacify" the city in mid-1570. After Goiti failed to subjugate the city, Legazpi personally commanded a new expedition in May of 1571, accompanied this time by hundreds of Cebuano warriors. Although Manila's dwellers fled inland burning their houses behind them, Legazpi settled in the city. A few days later, he received the indigenous rulers of Manila and Tondo, Raja Ache and his heir Raja Soliman, and Raja Sibanao Lakandula.

The encounter between the Spanish captain and the native chiefs epitomized the subjugation of Manila as a pact of vassalage. The Spanish account, called "protocol of pacification", described the meeting in line with the principles that sustained the incorporation of Manila's inhabitants as vassals of the Spanish Crown. The first principle was the voluntary election of a new sovereign. Manila's principales assembled with other native lords of neighboring towns to discuss "whether it would be good for them to make peace and friendship with the Spaniards and be His Majesty's vassals". They then agreed

\footnotetext{
$40 \quad$ King Philip II, "Reply to Miguel López de Legazpi”, vol. 34, 230-235.

$41 \quad$ King Philip II, "Reply to Miguel López de Legazpi".

42 King Philip II, "Instructions given to Miguel de López de Legazpi", ed. Emma H. Blair and James A. Robertson, vol. 34, 242.

43 Santiago, "The Houses of Lakandula, Matandá and Solimán”; Majul, Muslims in the Philippines; Saunders, A History of Brunei, 49-53.
} 
that "with common consent, they wanted to be vassals of the King of Castile".44 Through this action, the protocol highlighted the natives' free will to become vassals on the basis of a voluntary election of a new lord: King Philip II. On account of the nature of the sources, however, one can only speculate about the Spanish expectations and it cannot be affirmed that natives voluntarily became subjects of the Crown. What the document however does reveal is that the normative foundation of Spanish justifications for conquest had shifted from the requerimiento to pacts of vassalage.

The second principle of the protocol emphasized the providential mission that justified the Philippine expedition. Legazpi explained that he "came to these villages by command of His Majesty the King of Castile Don Felipe (King Philip II)", who wanted to "make [the Philippine rulers] know the true almighty God". After hearing that the king's central aim was to propagate "the holy Catholic faith so that they might be saved and not condemned", the principales responded "happily to be His Majesty's vassals", implicitly accepting religious conversion. ${ }^{45}$

The third principle meant that the protocol guaranteed principales the king's protection as a result of the vassalage compact. The Spanish captain explained that "if any Spaniard or any other person in his company does any harm to them or takes anything from them by force and against their will", he would act on behalf of the king as judge to "maintain peace and justice [among the natives] as vassals of His Majesty".46 Thus, the protocol of pacification sealed the pact of vassalage promising the eventual establishment of laws, institutions, and magistrates able to guarantee their wellbeing. On paper, the benefits for indigenous vassals appeared attractive. In practice, however, adherence to the contract proved difficult for the Crown. Lack of human resources and the rapid growth of the encomenderos' hegemony in the archipelago, explained in the following section, hindered the Crown's pledge to dispense justice to its native vassals.

\section{Justice in the Early Colonial Philippines}

The idea of justice fashioned the development of the judicial model of government in the Philippines. The Spanish king held supreme jurisdiction, which was represented in the Philippines by different officeholders. Since the

\footnotetext{
44 AGI, Patronato, 24, r. 24, fol. 1 .

45 AGI, Patronato, 24, r. 24, fol. 1r.

46 AGI, Patronato, 24, r. 24, fol. $1 v$.
} 
beginning of the colonial era, the governor stood at the apex of the institutions. Legazpi's pacification instructions had entitled him, as the supreme representative of royal authority, "governor general appointed by His Majesty". 4 After the conquest of Cebu, the Crown invested him and his successors with supreme judicial authority in royal ordinary justice, i.e. "civil and criminal justice", ${ }^{48}$ over all the inhabitants of the islands. Since then, the governor's main function was to "execute [the king's] royal justice there [the Philippines]".49 Having full ordinary jurisdiction, the governor could "open and determine all lawsuits and civil and criminal cases"50 concerning both the Spaniards and the natives. In addition, he and his delegates could remand "the foresaid [natives]" to make "any inquiries about the cases of rights, premises, and all other things [that] you consider are for the service of the royal justice".51

This delegation determined that the exercise of justice in the islands orbited and stemmed from the governor. His influence increased when the Crown granted him the right to allocate encomiendas-assignments of indigenous labor drafts to Spanish conquistadors in exchange for their military services and support in providing Christian education to their indigenous wards. In 1568, the Crown gave Legazpi and his successors the right to "encomendar (grant encomiendas) and distribute the towns you deem necessary, in accordance with the laws of succession of the indios". ${ }^{52}$ Governors leveraged this decree to benefit their close relatives and friends-a situation that favored the rapid growth of the encomiendas in the archipelago. ${ }^{53}$

As a result, during the first decade after the conquest of Manila, the encomiendas populated the Philippine landscape. In 1582, Spanish conquistador Miguel de Loarca reported to the Council of the Indies that Spanish soldiers together with their indigenous allies had conquered most of the archipelago. Analysis of the report reveals that indigenous male tributaries amounted to 141,840 . Of this number, 100,520 were allocated as encomiendas to about 120 Spanish conquistadors, while the remaining 41,320 were direct tributaries of the Crown. In the entire Philippines, only 800 indigenous inhabitants in Cebu were exempt from tributes "for having always been in favor of the Spaniards and helping to gain part of the other islands". ${ }^{4}$ Thus, Loarca concluded that almost "all the

AGI, Patronato, 23, r. 12. fol. 8r.

AGI, Filipinas, 339, L.1, fol. 24r.

AGI, Filipinas, 339, L.1, fol. 24r.

AGI, Filipinas, 339, L.1, fol. 24V.

AGI, Filipinas, 339, L.1, fols. 24V-25r.

AGI, Filipinas, 339, L.1, Fols. 1r-2v.

Hidalgo Nuchera, Encomienda, tributo y trabajo, 58-58.

AGI, Patronato, 23, r. 9. Philippine principales and their descendants were exempt from tribute payment because of their nobility status. Thus, the exemption granted to Cebu's indigenous commoners is a unique case in the entire Philippines. 
islands and populations that are at the service of His Majesty"55 were allocated as encomiendas.

In advancing the pacification of the archipelago, Spanish governors founded five settlements, where the few Spanish colonists settled to manage their encomiendas. The towns were Manila (Central Luzon), Cebu (Cebu island), Villa de Arévalo (Panay island), Villa de Cáceres (Bicol, southern Luzon), and Villa Fernandina (Ilocos, northern Luzon). Each of these organized the administration of justice and the management of indigenous tribute payments in the early colonial Philippines. As a result, there were seven major provinces in the archipelago: Manila (39,88o tributaries, subject to Manila), Cebu (24,10o tributaries, subject to Cebu), Panay (25,06o tributaries, subject to Villa de Arévalo), Bicol (28,700o tributaries, subject to Villa de Cáceres), Pangasinan (14,30o tributaries), Mindoro (no data), and Ilocos (12,200 tributaries) — the last three subject to Villa Fernandina.

Each of these Spanish towns and the settlements enjoyed limited self-government: they had a cabildo formed by regidores, who were deputies in charge of the urban management, and alcaldes ordinarios, who were local judges administering justice within the town. The towns were also the seat of provincial authorities - the alcalde mayor and the corregidor — who carried out the fundamental mission of tribute payment collection and held jurisdiction over the natives living in the countryside.

Each Spanish province governed extensive territorial areas and thus the indigenous tributaries greatly outnumbered the available magistrates. The provinces of Cebu, Panay, Bicol, Pangasinan, Mindoro, and Ilocos only had one alcalde mayor each. As a result, only six magistrates were available to dispense justice over more than one hundred thousand indigenous subjects.

In Manila and its surroundings, the situation was slightly different. Given that Central Luzon was the most populated and richest region of the islands, since 1576 the Crown had been taking most of the indigenous tributaries from the encomenderos to put under its dominion. ${ }^{56}$ To improve tribute payment collection, the Crown organized the region into ten jurisdictions managed by eight alcaldes mayores (Calompit, Candaba, Lubao, Bulacan, Tondo, Bahi, Cavite, and Laguna Bay) and two corregidores or provincial judges (Batan and Balayan). In the entire archipelago, the total of the tributary population $(141,840)$ divided by the total of colonial magistrates (15) results in an average of one Spanish judge to 10,313 tributaries-not counting women, young people, and the elderly. Loarca's report reasoned that all the Spanish authorities were encomenderos, "because if they were not encomenderos they could not sustain 
themselves". Alcaldes mayores visited the indigenous communities under their jurisdiction once a year to collect taxes and attend the "Indian lawsuits (pleitos de indios) $[. .$.$] and other commissions committed to justice". { }^{57}$ Although the Crown mandated that Spanish colonists with encomiendas, including the authorities, must reside in their estates, all of them preferred to settle in one of the Spanish towns.

Such an imbalance between magistrates and population and the fact that the former held encomiendas posed two major challenges that prevented the natives from receiving proper justice. First, magistrates failed to meet the demands of the indigenous population given the large number of cases that they had to attend each year. In the words of Don Pedro Lumano, a Pampanga principal, it was common that the indigenous communities "were worn out and destroyed among themselves in disputes and differences of the past".58 When the alcaldes mayores arrived at the indigenous towns to administer justice, they and their notaries merely registered the lawsuits in writing without issuing a decision. The lack of resolutions reached the point that, according to principal Don Juan Lisin, the judge died or was replaced by a new one and then he "heard [the cases] again and every day the lawsuits and the pleitantes (litigants) grew". Lisin also declared that this led the natives to invest a lot of resources and time in demanding justice, since "the indios of this land are noveleros (novices) [and] they put forward unreasonable lawsuits among themselves [...] spending their goods on this".59 The colonial magistrates benefited from this situation by registering the disputes without resolving them, while the indios became impoverished because they tended to leave "their houses and plots [...] all of them giving [the judges] large sums in fees because the naturales did not know about tariffs". 60

Second, there were exploitations committed by the colonial administration against natives, which both secular and ecclesiastical agents extensively reported to the Crown. As encomenderos, the magistrates naturally put their personal interests first at the expense of the proper administration of justice. After Legazpi's sudden death in 1572, the encomenderos took advantage of the freedom to exploit and deprive the natives. Conquistador Guido de Lavezaris, who succeeded Legazpi as governor, granted both encomiendas and justice posts to his fellow conquistadors. Missionary Martín de Rada explains that the natives arrived at Manila "to ask for justice but are badly heard and attended

57 Filipinas, 339, L. 2, fols. 134r-134v.

58 AGI, Filipinas, 34, n. 91, fols. 1014r-1028v.

59 AGI, Filipinas, 34, n. 91, fol. 1015v.

6o AGI, Filipinas, 34, n. 91, fol. 1016r. 
to because the governor and his officials are encomenderos". ${ }^{61}$ In Rada's opinion, the encomenderos' greed eroded the contractual relationship of vassalage: rather than vassals, Philippine natives had been turned into slaves. ${ }^{62}$

A decade later, since the mistreatments persisted, Manila's procurador (solicitor), Gabriel Rivera, made three propositions before the Council of the Indies to solve the mismanagement of justice in the islands. First, he proposed that the governor should be the only judge in charge of hearing and deciding on the indigenous lawsuits. As "most of the alcaldes ordinarios have encomienda" and it is common that the natives "receive many grievances and justice is not given to them", ${ }^{63}$ the governor should be more active in dispensing justice in his capacity as the highest judge in the islands. Second, the Crown should appoint a protector de indios to provide the natives with legal aid in their demands for justice. The indios, as "newly converted and pacified people [...] have no understanding or ability to defend themselves", and are thus in need of a "protector general defensor (general solicitor defender) with enough power" to take the natives' causes before the royal courts. ${ }^{64}$ Third, Rivera requested the creation of a Real Audiencia in Manila "for the Audiencia of Mexico to which [the inhabitants of the Philippines] go on appeal is so far away and this thus lacks justice". ${ }^{65}$ As Garriga explains, since the Crown proclaimed the New Laws in 1542 to protect its indigenous vassals, the Reales Audiencias became the highest provincial court embodying the supreme jurisdiction of the king. A Real Audiencia mainly served as a regional court of appeal for both civil and criminal cases and its main objective was to "correct" the judgments that colonial magistrates may have reached in bad faith. ${ }^{66}$

At this time, there was no Real Audiencia in the Philippines as "the appeals concerning the cases and litigation dealt with by the governor of the said islands take place in the Real Audiencia of Mexico". When Manila became capital of the archipelago in 1574, the Crown mandated that it was "fair that the government there was united and dependent on the government of New Spain" so that "the laws concerning government and justice keep the same order they

61 "toman por la fuerza de las armas lo que encuentra en los pueblos [...] es demasiado e insoportable el tributo [in gold] que se les lleva según la miseria de los naturales [...] y aunque vienen a pedir justicia [the natives] son muy mal oídos y despachados, al fin como así el gobernador y sus oficiales son todos encomenderos". AG I, Filipinas, 84, n. 4, fols. Ir-1v.

62 AGI, Filipinas, 84, n. 4, fol. iv.

63 AGI, Patronato 25, r. 2, fol. 3 v.

64 AGI, Patronato 25, r. 2, fol. 4 r.

65 AGI, Patronato 25, r. 2, fol. 1r.

66 Garriga, "Sobre El Gobierno". 
have" in New Spain. ${ }^{67}$ The incorporation of the Philippines into the jurisdiction of the Mexican Audiencia made judicial appeals extremely costly and complicated because of the huge distance between Manila and Mexico City. Only wealthy individuals could appeal to the king's court, while the indigenous subjects, who were neophytes in Spanish legal culture and had been exploited by the encomenderos, could not afford long-distance litigation.

Aiming to bring the king's justice to the distant Philippines, in 1584 the Crown established the Real Audiencia of Manila. Aside from attending appeals filed by Spaniards, the Audiencia also had to "take great care to be informed of the crimes and abuses which shall be committed, or have been committed, against the indios who shall be under our royal Crown". In consequence, the fiscal of the Audiencia was the main person in charge of assisting the "poor indios in the suits being carried out, and seeing to it on their behalf that they are not oppressed, maltreated, or wronged".68

The Audiencia also acted as advisory council to the governor, which caused bitter confrontations between them. The struggle for power led to the suppression of the tribunal in 1590 and the creation of a new one six years later. The first Audiencia not only engendered disputes with the highest official in the islands - the governor - but was also unable to provide legal aid to indigenous subjects. From 1598-16oo, the second Audiencia and the governor produced the first laws to reform the behavior of the colonial government and to improve the conditions of Philippine natives. ${ }^{69}$ Yet, the huge gap between the number of inhabitants and the magistrates available remained. Such a situation-not exceptional, but rather common in the empire-did not impede the Spanish Crown from governing over thousands of diverse indigenous communities scattered across the archipelago. Beneath the jurisdiction held by Spanish magistrates there was a different level of government that assured the regular collection of tribute payments and the daily administration of justice: indigenous jurisdiction.

\section{4 The Making of Indigenous Jurisdiction: Principales and Barangays}

The acknowledgement of indigenous jurisdiction in the Philippines dates to the conquest of Cebu in 1565. In the vassalage compact between Legazpi and

\footnotetext{
67 AGI, Filipinas, 339, L.2, fol. 49r.

68 Blair, Emma H. and James A. Robertson, "Foundation of the Audiencia of Manila", vol. 5, 261-304.

69 See Hidalgo Nuchera, Los autos acordados, 19-37.
} 
Cebu's natives, the Spanish captain set up a clause specifying that "if any indio natural of this island commits any crime or evil against any Spaniard $[. .$.$] the$ principales are compelled to catch them and bring them as prisoners before the governor so he can punish them and put them on trial".70 Thus, Legazpi confirmed the principales' authority as petty justice agents in charge of apprehending indigenous delinquents. Yet, the principales were not recognized as judges, although Spaniards acknowledged that, before they arrived at the archipelago, only the principales "are defenders and executors" of the public order, who "punish the crimes and also give laws" to their communities. ${ }^{71}$ The jurisdiction or the ability to dispense justice was reserved for the governor and, in consequence, his lieutenants, who were the alcaldes mayores.

This paralleled the Spanish American experience, where the Crown had seized the administration of justice from the indigenous nobility by creating a Spanish provincial government. From 1550, the Crown invested the corregidores and alcaldes mayores with judicial authority to "know of the grievances that were done to indios, punish those who do them, and dispense justice". ${ }^{72}$ The same judicial model functioned in the Philippines during the first three decades (1565-1595) of colonial dominion.

In royally appointing provincial magistrates, the Crown pursued two objectives. First, it aimed to enforce and expand the royal jurisdiction to the detriment of the encomenderos by appointing a judiciary that would resolve and punish "crimes committed between some españoles and others, and between indios and españoles". ${ }^{73}$ Second, the new provincial magistrates would end the "tyrannies" that the indigenous nobility supposedly committed against its subjects, who frequently claimed that not only the encomenderos, but also their caciques maltreated them.

At the same time that the provincial Spanish magistrates came on the scene, the Viceroys of New Spain and Peru introduced the cabildo in the indigenous towns. Native deputies and judges, annually elected to manage each town and the corresponding daily dispensation of justice involving minor crimes, formed the indigenous cabildo. ${ }^{74}$ The creation of cabildos meant that native agents outside the traditional nobility class upheld civil jurisdiction within their towns for the time they served in the town council. The strategy allowed the Crown to assert control over the labor and tribute of its indigenous vassals,

\footnotetext{
70 “Relación sobre los sucesos de Cebú", AG I, Patronato 23, r. 22, fol. 4r.

71 AGI, Patronato, 23, r. 9.

72 Encinas, Cedulario Indiano, vol. III, 19.

73 Encinas, Cedulario Indiano, vol. III, 19.

74 Haskett, Indigenous Rulers, 77-82.
} 
while the representatives of the indigenous communities acquired limited civil jurisdiction to dispense justice over the indigenous members of the town. ${ }^{75}$

A similar process of empowerment of indigenous agents as judges unfolded in the Philippines from the $158 \mathrm{os}$, however in this case the indigenous nobility did not lose its jurisdiction but recovered it. Dominican friar and theologian Domingo de Salazar, the first Bishop of the Philippines, stood out as the main defender of the indigenous subjects and the Philippine principales. As Guillaume Gaudin explains, the creation of the Bishopric of Manila (1579) and the appointment of Salazar in the episcopal see of the archipelago sought to moderate the power of the governor, to reaffirm the royal authority over the monastic orders, and to grant justice to natives. ${ }^{76}$ As missionary and solicitor of the Dominican order in New Spain, Salazar demonstrated a combative spirit in favor of the peaceful conversion and submission of the natives. ${ }^{77}$ When he arrived in Manila, he rapidly became the most formidable opponent to the encomenderos and the colonial government by denouncing their actions directly to the king.

In 1582, Salazar celebrated a synod that gathered all the secular and religious authorities of the Philippines. The synod's purpose was to solve the major problem facing the indigenous vassals: that alcaldes mayores were also encomenderos. Salazar's main concern was that this combination prevented the natives from receiving proper administration of justice and religious education. ${ }^{78}$ Through the synod of Manila, Salazar expected to effect change by setting norms of behavior for the Spanish colonizers and asking for the judicial empowerment of the Philippine principales.

In the council, Salazar drew two radical conclusions. First, Spanish conquistadors had conducted military campaigns without respecting the pacts of friendship and vassalage established in the pacification instructions. Therefore, all the goods they had taken from the natives should be restituted by investing in the construction of churches for the missionary enterprise, since Spanish dominion's primary purpose was that of Christian conversion. If the governor and the officials did not comply with such restitution, Salazar would denounce that the conquest of the Philippines had been attained illegally. ${ }^{79}$

Second, Salazar suggested that Spaniards "caused the indios great harm by thinking they are not capable of governing themselves, because [Spaniards]

75 Menegus, Del señorío a la república de indios, 77-93; Mumford, Vertical Empire, 75-80.

76 Gaudin, "Estableciendo la autoridad del rey".

77 Porras Camúñez, Sínodo de Manila, 36-49.

78 Porras Camúñez, Sínodo de Manila, 9-11.

79 Salazar, Suma de una junta, lib. I, cap. $7,16$. 
neither understand them nor know their language and their customs". Salazar went even further, stating that, if Spaniards understood indigenous peoples, "we would see that they could govern themselves as well as we do, and that perhaps we are more barbaric to them than they are to us". ${ }^{80}$ Although the bishop and his religious companions asserted that Philippine peoples lacked "good government", they considered that a better comprehension of indigenous customs would improve the justice and conversion of Philippine natives. ${ }^{81}$

In denouncing the barbaric ways in which Spaniards treated the natives, Salazar demanded the restitution of the principales' jurisdiction within their communities by empowering them as local magistrates. He urged the governor "to appoint Indian judges, elected by the indios themselves, in the more populated villages", so that native subjects "could ask for common justice and policía (order) and ordinary cases" before their own authorities. Such a proposal, Salazar highlighted, was according to "the natural law, since nature itself shows that even brute animals [...] have governors and heads of their same república (republic)" and not from a different one. The bishop thought it necessary "that the governor [of the natives] must be of the same kind when the conditions allowed it", and that the granting of justice must "be trusted to an indio, by giving him jurisdiction over the rest" of the indigenous population. A good judge and governor needed to possess a "knowledge of his república and its laws, customs, and abuses". For all these reasons, Salazar concluded, "the governor should, under pain of mortal sin, appoint these Indian judges" as a means to restitute all the injustices that Spaniards had brought upon indigenous peoples. ${ }^{82}$

As expected, Salazar's project faced strong challenges in finding its place in the colonial institutions. Both the encomenderos and the Real Audiencia of Manila rejected the synod's proposal. Yet, the major challenge of the bishop's plan to create autonomous indigenous jurisdictions was that, as he stated in the synod, Spaniards ignored indigenous customs. The restitution of the principales' jurisdiction required knowledge of indigenous customs since they

8o Anon., Junta y congregación, lib. I, cap. 1, § 11-13.

81 Salazar, Suma de una junta, lib. I, cap. 1, 6.

82 "Supuesto es justa la jurisdicción del Rey y su Gobernador en esta tierra, decimos que el gobernador, fuera de los alcaldes mayores, debe poner en los pueblos mayores y más asentados jueces indios elegidos por los mismos indios [...] porque es derecho natural, que la misma naturaleza enseña aún a los brutos animales, y así vemos que las grullas, hormigas y abejas tienen gobernador y cabeza de su misma república y no de otras; y entre los mismo del cuerpo que gobierna es uno de ello [...]. Y por esta razón pareció debía el Gobernador, bajo pecado mortal y restitución de los daños que se siguieren, poner estos jueces indios donde hubiese disposición". Salazar, Suma de una junta, lib. I, cap. 17, 24-25. 
delineated both the territorial limits and the legal matters that indigenous nobility would oversee.

In the Spanish colonization of America, the endorsement of an indigenous judiciary accompanied the incorporation of indigenous customs into the normative corpus of the Spanish empire. In 1555, a royal decree mandated to preserve the "good customs and laws that the indios used to have for their governance and policía" as long as they were not contrary to the Christian faith. ${ }^{83}$ As Hespanha explains, Iberian jurists conceived indigenous customs as "rustic law" (direito rústico). According to him, indigenous customs, were considered an inferior legal reality since they derived from the ignorance of barbarian peoples. Still, indigenous customs were a legitimate source of law because they aimed to preserve the wellbeing of their communities. Therefore, royal magistrates should incorporate, through a process of compilation and selection, those elements of "rustic law" considered useful for the welfare of indigenous peoples that did not contradict Catholic morality. ${ }^{84}$

Salazar's proposal to recognize indigenous jurisdiction became reality when Franciscan Friar Juan de Plasencia met the task of compiling the Philippine indigenous custom. In 1589, Plasencia handed the Real Audiencia of Manila two works-Costumbres antiguas de los naturales de estas islas and Costumbres de los naturales de la provincial de Pampanga - in which he described the most important aspects of "government, justice, bequests, slaves, and dowries" according to the traditions and customs of the Tagalog and Pampangos, who inhabited Luzon island. ${ }^{85}$ Plasencia's works served as a guide for the Audiencia's magistrates concerning the ancient ways of justice among Philippine natives so they could "keep the customs that the foresaid naturales used to have and currently have in the foresaid lawsuits so they may be preserved as His Majesty commands". ${ }^{86}$

83 Encinas, Cedulario Indiano, 355 .

84 Hespanha, "As fronteiras do poder".

85 "he juntado indios de diferentes partes hombres viejos y los de más capacidad que yo conocía y sacada la verdad en limpio dejadas muchas impertinencias acerca de su gobierno y justicia, herencias y esclavos y dotes es lo que hay aquí". Since Plasencia reported before the Royal Audiencia de Manila, his works are inserted in a collection of decrees-reales cédulas and autos de buen gobierno — mandated by royal tribunal. "Cédulas sobre Filipinas, 1581 a 1594", BLAC, G56, fols. $511-56 \mathrm{v}$.

86 "conviene que los abogados y procuradores de esta Real Audiencia aleguen las costumbres de los dichos naturales que antes tenían y tienen en los dichos pleitos para que les sean guardadas como su majestad manda". "Cédulas sobre Filipinas, 1581 a 1594", BLAC, G56, fol. 45 v. Historiography has considered these works as key ethnographic sources, but Plasencia's original purpose was to compile the indigenous customs of Central Luzon. A 
Plasencia's research emphasizes the role of the barangay as the basic unit of social organization and, hence, of indigenous jurisdiction. He explains that the Tagalog "always had principales, whom they call datus, who ruled them", and who also wielded justice over a certain number of families; this set of households "is called barangay". ${ }^{87}$ A similar situation existed among the peoples of Pampanga. Plasencia explains that "they never had a head whom in general all the peoples obeyed but, in each barangay, they only obeyed one chief". Native commoners presented "their lawsuits to their principal", who sought to reconcile the opposing parties through oral trials with the participation of witnesses. ${ }^{88}$ Plasencia's inquiries show that the Tagalog and Pampanga peoples possessed customs in which the datus or principales played a central role in the exercise of justice, which supported Salazar's plan to restitute indigenous jurisdiction.

Plasencia's reports also demonstrate that the principales' jurisdiction encompassed the barangay. Regarding the Tagalog peoples, he explains that the datu was responsible for "judging and inquiring" about the crimes committed "within his barangay". A principal was the only judge within his community unless the native chiefs invited another principal from a neighboring barangay to act as an impartial judge. When "one of the parties felt aggrieved, they all agreed to appoint an arbiter judge from another barangay or town" so the neighboring principal could judge "the truth according to their customs". When the principales of the same barangay confronted themselves, or when two distinct barangays had disputes, the native chiefs also tended to "appoint arbiter judges". 89 Plasencia perceived that Philippine customs, in a similar way to the Spanish legal tradition, resorted to consultative meetings to dispense justice on the grounds of a common agreement among the magistrates. The barangay constituted the social unit that defined the limits of the principales' jurisdiction, but the principales could also assemble to form advisory councils to solve community conflicts.

short review of Plasencia's work to explain the concept of barangay and other notions of Tagalog and Pampanga peoples is in Scott, Barangay, $1-6$.

$87 \quad$ Plasencia, Costumbres antiguas, fol. 5 1r.

88 Plasencia, Costumbres de los naturales, fol. $54 \mathrm{v}$.

89 The complete title expresses: "El juzgar y averiguar sus competencias el dato lo hacía entre los de su barangay. Y si alguna de las partes se sentía agraviada, de conformidad todos nombraban un juez árbitro de otro barangay o pueblo, fuese dato o no, que para esto había ya algunos conocidos por hombres desapasionados y que decían y juzgaban la verdad según sus costumbres; y si era el pleito entre dos principales, cuando querían excusar guerras nombraban también jueces árbitros; y si era entre dos de diversos barangays, así mismo". Plasencia, Costumbres antiguas, title 9. 
Plasencia's works not only served as a guide for Spanish magistrates dealing with "Indian lawsuits", but also enhanced Salazar's project of recognizing indigenous jurisdiction, which the Crown finally endorsed in 1594. That year, a royal decree from King Philip II declared that, "having been informed that the indios principales were deprived of the señorio [dominion] they had in their gentility [...] I command you to treat them well and entrust them, in my name, with the government of the indios of which they were lords". ${ }^{90}$ Finally, the Crown recognized principales as legitimate governors of their barangays and, hence, guarantors of local justice since they were "lords" of their communities and held jurisdiction over them. Later, by the 1640 s, the colonial government developed the post of gobernadorcillo in line with the conciliar system that Plasencia described. In addition, the barangays now had to have a cabeza de barangay who represented his community (formed by 45-50 households), and each year the cabezas of a set of barangays assembled to elect a gobernadorcillo, who collected tribute payments and solved minor disputes in the communities that elected him. ${ }^{91}$ In creating the elective post of the gobernadorcillo, the Crown endorsed the "impartial arbiter" that Philippine communities used to recognize in their daily administration of justice.

Neither the royal decree that restituted the principales' jurisdiction nor any other later colonial decree specified in which legal matters and how the native chiefs could intervene. When the Crown reinstalled the Real Audiencia of Manila in 1596, it specified that, when possible, the "Indian lawsuits" at all jurisdictional levels must "be summarily determined, keeping their habits and customs as long as they were not clearly unjust". ${ }^{92}$ The insertion of Plasencia's works in the autos de buen gobierno - provisions of government collegially decided among all the members of the Audiencia — suggests that the colonial magistrates in the Philippines took them as reference to determine at their discretion which customs were "not clearly unjust". Ultimately, Spanish magistrates indistinctly drew from the opinions of jurists, from royal decrees and ordinances, and from custom-including the indigenous customs- to dispense justice in each case: giving each person what they were entitled to without custom or written law having precedence over the other.

\footnotetext{
90 "Cédulas sobre Filipinas, 1581 a 1594", B LAC, G56, fol. 175v.

91 Sánchez-Gómez, "Elecciones Locales Indígenas"; Sánchez-Gómez, "Estructura de Los Pueblos"; Alonso Álvarez, El costo del imperio, 124-134.

92 "Mando que los dichos mi presidente y oidores tengan mucho cuidado de no dar lugar que en los pleitos que entre indios o con ellos se hagan procesos ordinarios no haya largas sino que sumariamente sean determinados guardando sus usos y costumbres no siendo claramente injustos y los dichos mis oidores tengan cuidado que estos mismos se guarden por los jueces inferiores". AGI, Filipinas, 339, L.2, fols. 183v-185r.
} 
Unfortunately, there is little archival evidence available to decipher the practice and scope of indigenous jurisdiction in the Philippines; two aspects explain this gap. First, a substantial portion of documents concerning the colonial era perished because of the bombing and looting that unfolded during the Second World War. As Bruce Cruikshank notes, it is highly probable that the Philippine National Archives contained the records of the Real Audiencia of Manila, including thousands of "Indian lawsuits", that were destroyed amid the chaos of war. ${ }^{93}$

Second, in 159o, before the second Audiencia's orders, the Crown had already mandated the Spanish magistrates to "avoid any lawsuits and to solve them by good means without them reaching trial". When lawsuits had to be solved by trial, they had to be "brief and to the point without the ordinary deadlines and terms $[\ldots]$ to save expenses to the indios". Seeking to enhance the administration of local justice, the Crown stipulated that the provincial judges must proceed "summarily in civil matters and that minor cases should not be recorded in writing". Equally, if the Spanish judiciary was not required to keep written records on minor trials, it is also likely that, given the well-rooted oral culture of Philippine peoples, indigenous magistrates also did not think it necessary to record the daily dispensation of justice. ${ }^{94}$ Pending further archival discoveries, Spanish records are the only evidence available to assist with understanding indigenous jurisdiction and customs in the Philippines. Hidden and often ignored because of the lack of sources, justice imparted by Philippine principales was probably one of the cornerstones for the Spanish Crown in its governance and maintenance of its Asian possession for more than three centuries.

\section{5 Conclusion}

In 1596, two years after the restitution of the principales' jurisdiction, the Crown mandated the renewal of the pacts of friendship between the king and the Philippine peoples. From 1599-160o, through the mediation of missionaries, the principales performed the oath of vassalage pledging allegiance to the Spanish monarch while symbolically electing him, again, as their true and

\footnotetext{
93 Cruikshank, Filipiniana in Madrid, 1-7.

94 "su majestad en su real instrucción [has] mandado y ordenado que en estas islas se procure evitar cualesquiera pleitos y concordaos a buenas sin que lleguen a tela de juicio y que los pleitos que hubiere y no se pudieren excusar sean breves sumarios sin los plazos y términos ordinarios y que para evitar costas a los indios y otras molestias y gastos en ellos se proceda sumariamente mayormente en los civiles y que algunos de poca importancia no se escriban [...]." AGI, Filipinas, 34, n. 91, fols. 1014r-1028v.
} 
perpetual sovereign. ${ }^{95}$ The "Philippine referendum" — as defined by Phelan and Fidel Villarroel — vindicated the promise made by the protocols of pacification and the pacts of friendship from the conquest period: that the vassalage relationship between the king and the indigenous rulers was based on mutual obligations.

This paper traces the foundations of the pact and its impact on the development of the administration of justice and the colonial institutions in the early colonial Philippines. Before Legazpi arrived on the shores of the Philippines, the Crown had already projected to bestow upon Philippine natives the legal status of vassals. Drawing from the Thomistic concept of friendship, the Crown mandated to recognize Philippine native rulers as equal sovereigns to the Spanish king, a relationship that conveyed mutual responsibilities: protection and conversion in exchange for tribute payments. The friendship pacts between the natives and the king that unfolded during the conquest set the stage for the later development of a government that would ideally anticipate the protection and Christian conversion of the indigenous vassals. Yet, Spanish conquistadors soon took over the archipelago, by not only seizing indigenous labor through encomienda assignments, but also occupying the offices that supposedly guaranteed natives the king's protection. The abuses and mistreatments by the colonial government prompted Salazar, the first bishop of the Philippines, to effect change. In the Synod of Manila (1582), Salazar proposed to restitute the principales' jurisdiction, which meant to recognize them as local judges in charge of daily justice within their communities. Only when Franciscan Friar Plasencia compiled the customs of Tagalogs and Pampangos, which supported Salazar's proposal, did indigenous jurisdiction become another jurisdictional level in the Philippines that allowed the Spanish Crown to manage its Asian possession. The principales and their barangays became a key component of the institutions that assured Spanish rule in an archipelago of more than 7,000 scattered islands with extensive geographical and cultural diversity.

\section{Acknowledgements}

Research for this article has been possible thanks to the generous support of the Tom and Martha Ward Endowed Fund, the Department of History at the University of Texas at Austin, and the ConTex Doctoral Fellowship. I want to

95 Villarroel, "Philip II"; Phelan, "Some Ideological Aspects". 
express my gratitude to Ann Twinam, Nicholas Sy, Grace Concepcion, and my wife, Stephannie Coeto Coix, for their kind support. Their insightful comments and expertise have improved this study in innumerable ways. I also want to thank Manuel Bastias Saavedra and the two anonymous reviewers for their suggestions. All errors are mine.

\section{Bibliography}

\section{Manuscripts}

Archivo General de Indias, Sevilla (AGI), Filipinas, 34, n. 91.

Archivo General de Indias, Sevilla (AGI), Lima, 567, L.8, fols. 148r-151v.

Archivo General de Indias, Sevilla (AGI), Patronato, 23, r. 12.

Archivo General de Indias, Sevilla (AGI), Patronato, 180, r. 56.

Archivo General de la Nación, México (AGNM), Inquisición, vol. 72, exp. 32.

Archivo General de Indias, Sevilla (AGI), Patronato, 24, r. 24.

Archivo General de Indias, Sevilla (AGI), Patronato, 23, r. 22.

Archivo General de Indias, Sevilla (AGI), Filipinas, 339, L. 1.

Archivo General de Indias, Sevilla (AGI), Filipinas, 339, L. 2.

Archivo General de Indias, Sevilla (AGI), Filipinas, 84, n. 4.

Benson Latin American Collection, Austin (BLAC), Genaro García Collection, G56.

\section{Printed Sources}

Anon., Junta y congregación, ed. Porras Camúñez, José Luis, Madrid 1988.

Alfonso X, Las siete Partidas [...], ed. Real Academia de la Historia, Madrid 1807.

Blair, Emma H., Robertson, James A., The Philippine Islands [...], Cleveland 1909.

Covarrubias, Sebastián de, Tesoro de la lengua [...], ed. Luis Sánchez, Madrid 1611.

Encinas, Diego de, Cedulario Indiano, ed. García Gallo, Alfonso, Madrid 1990.

\section{Literature}

Agüero, Alejandro, "Las categorías básicas de la cultura jurisdiccional", in Lorente, Marta (ed.), De Justicia de jueces a justicia de leyes: hacia la España de 1870, Madrid 2006, 19-58.

Alonso Álvarez, Luis, El costo del imperio asiático. La formación colonial de las islas Filipinas bajo dominio español, 1565-180o, México 2009.

Andaya, Leonard Y., "Los primeros contactos de los españoles con el mundo de las Molucas en las Islas de las Especias", in Revista Española del Pacífico 2:2 (1992): 62-85. Bastias Saavedra, Manuel, "Jurisdictional Autonomy of Law: End of Empire and the Functional Differentiation of Law in 19th-Century Latin America", in Rechtsgeschichte-Legal History 26 (2018): 325-337. 
Barandica, Luis Abraham, "Andrés de Urdaneta en la Nueva España", in Barrón, Ma. Cristina (ed.), Urdaneta Novohispano: la Inserción del mundo hispano en Asia, México 2012, 35-66.

Bernabeú, Salvador, "Magallanes: retrato de un hombre", in Yuste López, Carmen and Pinzón Ríos, Guadalupe (eds.), A 500 años del hallazgo del Pacífico: la presencia novohispana en el Mar del Sur, México 2016, 21-52.

Borao Mateo, José E., "Contextualizing the Pampangos (and Gagayano) Soldiers in the Spanish Fortress in Taiwan (1626-1642)", in Anuario de Estudios Americanos 70:2 (2013): 581-605.

Cardim, Pedro, "Amor e Amizade Na Cultura Política Dos Séculos XVI e XVII", in Lusitania Sacra 11 (2000): 21-57.

Cervera, José Antonio, “¿Las Molucas o China? Filipinas y los planes para la expansión hispana a Asia Oriental desde la Nueva España en el siglo XVI", in Yuste López, Carmen and Pinzón Ríos, Guadalupe (eds.), A 500 años del hallazgo del Pacífico: la presencia novohispana en el Mar del Sur, México 2016, 101-124.

Conception, Grace L., "Negotiating Land in the Spanish Philippines: Cases of Land Donations and Boundary Disputes in Laguna, Seventeenth and Eighteenth Centuries", in Philippine Studies: Historical and Ethnographic Viewpoints 67:3 (2019): $285-313$.

Constable, Olivia Remie, To Live like a Moor: Christian Perceptions of Muslim Identity in Medieval and Early Modern Spain, Philadelphia 2018.

Cortés Pacheco, Carmen, "La amistad política en Santo Tomás de Aquino: entre la Justicia y la misericordia", in Espíritu: Cuadernos Del Instituto Filosófico de Balmesiana, no. 151 (2016): 101-127.

Crossley, John N., "Dionisio Capulong and the Elite in Early Spanish Manila (c. 15701620)", in The journal of the Royal Asiatic Society 28:4 (2018): 697-715.

Cruikshank, Bruce, Filipiniana in Madrid: Field Notes on Five Major Manuscript Collections, Honolulu 1984.

Duve, Thomas, "La Escuela de Salamanca: ¿un caso de producción global de conocimiento?: Consideraciones Introductorias Desde Una Perspectiva Históricojurídica y de la historia del conocimiento", in Duve, Thomas (ed.), The School of Salamanca. A Digital Collection of Sources and a Dictionary of Its Juridical-Political Language, Working Paper Series No. 2018-02.

Fioravanti, Maurizio, "Estado y Constitución”, in Fioravanti, Maurizio (ed.), El Estado moderno en Europa: instituciones y derecho, trans. Manuel Martínez, Madrid 2004, $13-44$.

Ganshof, François L., El feudalismo, trans. Feliu Formosa, Madrid 1979.

Garriga, Carlos, “Sobre el gobierno de la justicia en Indias (siglos XVI-XVII)", in Revista de Historia Del Derecho 34 (2006): 67-16o. 
Garriga, Carlos, "Las Audiencias: justicia y gobierno de las indias" in Barrios Pintado, Feliciano (ed.), El gobierno de un mundo:virreinatos y audiencias en la América hispánica, Cuenca 2004, 711-794.

Gaudin, Guillaume, "Estableciendo la autoridad del rey católico en Asia oriental: la erección del obispado de Manila (años 1570-1590)", in Caravelle, no. 113 (2019): $125^{-138 .}$

Gil Pujol, Xavier, "The Good Law of a Vassal: Fidelity, Obedience and Obligation in Habsburg Spain", in Elliott, John H. and Arrieta, Jon (eds.), Revista internacional de estudios vascos, serie cuadernos 5 (2009): 83-106.

González Arévalo, Raúl, "Cautiverio y esclavitud en el reino de Granada (siglos XIIIXVI)", in Vínculos de Historia, no. 3 (2014): 232-257.

Greenleaf, Richard E., Zumárraga y la Inquisición mexicana, 1536-1543, México 1988.

Gruzinski, Serge, El águila y el dragón: desmesura europea y mundialización en el siglo $X V I$, trans. Mario Zamudio, México 2018.

Haskett, Robert S., Indigenous Rulers: An Ethnohistory of Town Government in Colonial Cuernavaca, Albuquerque 1991.

Hera, Alberto de la, "El dominio español en indias", in Sánchez Bella, Ismael, Alberto de la Hera and Carlos Díaz Rementería (eds.), Historia del derecho Indiano, Madrid 1992, 109-164.

Herzog, Tamar, Los ministros de la Audiencia de Quito (1650-1750), Quito 1995.

Hespanha, António Manuel, "As fronteiras do poder. Os mundos dos rústicos", in Seqüência, no. $5^{1}$ (2005): 47-105.

Hespanha, António Manuel, As vésperas do leviathan. Instituições e poder político: Portugal- séc. XVII, Coimbra 1994.

Hess, Andrew C., "The Moriscos: An Ottoman Fifth Column in Sixteenth-Century Spain", in The American Historical Review 74:1 (1968): 1-25.

Hidalgo Nuchera, Patricio, Encomienda, tributo y trabajo en Filipinas, 1570-1608, Madrid 1995 .

Hidalgo Nuchera, Patricio, La recta administración. Primeros tiempos de la colonización hispana en Filipinas: la Situación de la población nativa, Madrid 2001.

Hidalgo Nuchera, Patricio, Los Autos acordados de la Real Audiencia de las Islas Filipinas de 1598 y 1599, Madrid 2012.

Knauth, Lothar, "Los dos Fernandos: prerrogativas comerciales y afán territorial en los proyectos transpacíficos”, in Barrón, Ma. Cristina (ed.), Urdaneta Novohispano: la Inserción del mundo hispano en Asia, México 2012, 19-34.

León-Portilla, Miguel, "Lo que supo y no supo Hernán Cortés acerca del oceáno Pacífico", in Yuste López, Carmen and Guadalupe Pinzón Ríos (eds.), A 500 años del hallazgo del Pacífico: la presencia novohispana en el Mar del Sur, México 2016, 53-82.

Majul, Cesar A., Muslims in the Philippines, Quezon City 1999. 
Mawson, Stephanie, "Philippine Indios in the Service of Empire: Indigenous Soldiers and Contingent Loyalty, 16oo-1700", in Etnohistory 63:2 (2016): 381-413.

Menegus Bornemann, Margarita, "Alcabala o tributo. Los indios y el fisco (siglos XVI al XIX). Una encrucijada fiscal", in Jáuregui, Luis and Antonio Serrano (eds.) Las Finanzas Públicas En Los Siglos XVIII-XIX, México 1988, 110-130.

Menegus Bornemann, Margarita, Del señorío a la república de indios: el caso de Toluca, 1500-1600, Madrid 1991.

Mumford, Jeremy R., Vertical Empire: The General Resettlement of Indians in the Colonial Andes, Durham 2012.

Muro, Luis, La expedición Legazpi-Urdaneta a las Filipinas (1557-1564), Mexico 1975.

Ollé, Manel, “A inserção das Filipinas na Ásia Oriental (1565-1593)", in Review of Culture 7 (2033): 7-22.

Phelan, John L., "Some Ideological Aspects of the Conquest of the Philippines", in The Americas 13:3 (1957): 221-239.

Phelan, John L., The Hispanization of the Philippines: Spanish Aims and Filipino Responses, 1565-1700, Madison 1959.

Porras Camúñez, José Luis (ed.), Sínodo de Manila de 1582, Madrid 1988.

Premo, Bianca and Yanna Yannakakis, "A Court of Sticks and Branches: Indian Jurisdiction in Colonial Mexico and Beyond", in American Historical Review 124:1 (2019): 28-55.

Reynolds, Susan, Fiefs and Vassals: The Medieval Evidence Reinterpreted, Oxford 1994.

Ruiz Medrano, Ethelia, Mexico's Indigenous Communities: Their Lands and Histories, 1500-2010, trans. Russ Davidson, Boulder 2010.

Sánchez-Gómez, Luis A., "Elecciones locales indígenas en Filipinas durante la etapa hispánica", in Rodao, Florentino (ed.), Estudios sobre Filipinas y las Islas del Pacífico, Madrid 1989, 53-61.

Sánchez-Gómez, Luis A., "Estructura de los pueblos de indios en Filipinas durante la etapa española”, in Rodao, Florentino (ed.), España y el Pacífico, Madrid 1989, 81-116.

Santiago, Luciano P. R., "The Houses of Lakandula, Matandá and Solimán (1571-1898): Genealogy and Group Identity", in Philippine Quarterly of Culture and Society 18:1 (1990): 39-73.

Sanz y Díaz, José, Legazpi: conquistador de Filipinas, 2nd ed., Madrid 1959.

Saunders, Graham E., A History of Brunei, New York 1994

Scott, William H., Barangay: Sixteenth-Century Philippine Culture and Society, Manila 1994.

Semboloni, Lara, La construcción de la autoridad virreinal en Nueva España, 1535-1595, México 2014.

Tau Anzoátegui, Víctor, El jurista en el Nuevo Mundo: pensamiento. Doctrina. Mentalidad, Frankfurt am Main 2016. 
Vallejo, Jesús, "El cáliz de plata. Articulación de órdenes jurídicos en la jurisprudencia del Ius Commune", in Revista de historia del derecho, no. 38 (2009): 1-13.

Villarroel, Fidel, "Philip II and the 'Philippine Referendum' of 1599", in Lario, Dámaso de (ed.), Re-Shaping the World: Philip II of Spain and His Time, Manila 2008, 93-133.

Wagner, Andreas, "Francisco de Vitoria", in Domingo, Rafael and Javier Martínez-Torrón (eds.), Great Christian Jurists in Spanish History, Cambridge 2018, 84-96. 